\section{Advanced maternal age and its association with placenta praevia and placental abruption: a meta-analysis}

\author{
Idade materna avançada e sua associação com \\ placenta prévia e descolamento placentário: \\ uma metanálise
}

\section{Edad materna avanzada y su asociación con placenta previa y desprendimiento de la placenta: un metanálisis}

Katrini Guidolini Martinelli 1,2

Érica Marvila Garcia 1

Edson Theodoro dos Santos Neto 1

Silvana Granado Nogueira da Gama 2

doi: 10.1590/0102-311X00206116

\begin{abstract}
This study aimed to investigate the existence and magnitude of the association between advanced maternal age (AMA) and occurrence of placenta praevia $(P P)$ and placental abruption (PA) among nulliparous and multiparous women, by a systematic review and meta-analysis. We searched articles published between January 1, 2005 and December 31, 2015, in any language, in the following databases: PubMed, Scopus, Web of Science, and LILACS. Women were grouped into two age categories: up to 34 years old and 35 years or older. The Newcastle-Ottawa Scale was used to evaluate the methodological quality of the studies. A meta-analysis was conducted for the PP and PA outcomes, using a meta-regression model to find possible covariates associated with heterogeneity among the studies and Egger's test to assess publication bias. The protocol of this systematic review was registered in the International Prospective Register of Systematic Reviews (PROSPERO) system (CRD42016045594). Twenty-three studies met the criteria and were included in the meta-analysis. For both outcomes, an increase in age increased the magnitude of association strength, and $P P(O R=3.16,95 \% C I: 2.79-3.57)$ was more strongly associated with AMA than $P A(O R=1.44,95 \% C I: 1.35-1.54)$. For parity, there was no difference between nulliparous and multiparous women considered older for the PP and PA outcomes. Our review provided very low-quality evidence for both outcomes, since it encompasses observational studies with high statistical heterogeneity, diversity of populations, no control of confounding factors in several cases, and publication bias. However, the confidence intervals were small and there is a dose-response gradient, as well as a large magnitude of effect for PP.
\end{abstract}

Maternal Age; Placenta Previa; Abruptio Placentae; Pregnancy Complications
Correspondence

K. G. Martinelli

Rua Inacio Higino 1170, apto. 608A, Vila Velha, ES 29101-094, Brasil.

katrigm@gmail.com

1 Universidade Federal do Espírito Santo, Vitória, Brasil. 2 Escola Nacional de Saúde Pública Sergio Arouca, Fundação Oswaldo Cruz, Rio de Janeiro, Brasil. 


\section{Introduction}

Modern social life has considerably affected the reproductive life of women, especially since the $1980 \mathrm{~s} 1$. The number of nulliparous women with advanced maternal age (AMA) - defined as maternal age greater than or equal to 35 years at childbirth, according to the International Federation of Gynecology and Obstetrics 2 - has increased in recent years ${ }^{3}$, especially in developed countries and among women of higher social classes in developing countries 4. Prioritizing their education level, investing in their career, as well as new relationships, have led women to postpone motherhood or repeat it at more advanced ages $5,6,7$, ignoring possible risks associated with late pregnancy 8 .

Studies have shown an association between AMA and gestational complications, such as gestational diabetes, gestational hypertension, C-section, preeclampsia, premature rupture of membranes, and chromosomal fetal anomalies 9,10,11,12,13,14. However, the evidence is inconclusive regarding the association of AMA with placenta praevia (PP) and placental abruption (PA), with some studies indicating a positive association $12,14,15,16$ and others showing no statistically significant association $13,17,18,19,20,21,22,23,24,25$.

PP is an obstetric complication in which the placenta partially or completely obstructs the internal orifice of the cervix, with an incidence of $0.3 \%$ to $2 \% 26$. PA results from a cascade of pathophysiological processes that lead to placental separation prior to delivery, complicating about $1 \%$ of births 27 . Both are important causes of bleeding in the second half of pregnancy, and have been associated with serious maternal complications, such as hemorrhaging - one of the three leading causes of maternal death in the world 28 . Similarly, perinatal mortality is shown to be 10 times higher among women with PA after 35 gestational weeks compared to women with no complications 29.

This study aimed to investigate the existence and magnitude of the association between AMA and the occurrence of PP and PA among nulliparous and multiparous women, by a systematic review and meta-analysis.

\section{Materials and methods}

To identify relevant and up-to-date studies, we initially planned to search for articles published between January 1, 2005 and December 31, 2014. However, because of a delay in completing the review, all the months of 2015 were also included. We searched for studies in any language, in the following databases: PubMed, Scopus, Web of Science, and LILACS. Table 1 shows the search strategy for the PubMed database. Equivalent strategies were adopted for the other databases. To identify additional studies, the bibliographic references were verified, and publications considered relevant were searched manually.

For searching, selecting, and extracting the data, we used a preestablished protocol. After screening the articles that were found by the search strategy, we selected those that appropriately met the following inclusion criteria: (a) to be published between January 1, 2005 and December 31, 2015; (b) have the outcomes of interest - PP (all types: total praevia, partial praevia, marginal praevia, and lowlying placenta) or PA - in the results; (c) not only include women who underwent in vitro fertilization; (d) include women who presented PP or PA and compare their frequency by age group: 35 years or older (AMA) and up to 34 years old (younger women); (e) provide necessary data, such as number of participants, number of outcomes in each group, or odds ratio with confidence interval; (f) consider advanced maternal age from 35 years on; and (g) include only cohort studies in the meta-analysis. The inclusion criteria from "a" to "f" as methods of analysis, were specified in advance and documented in a protocol in the International Prospective Register of Systematic Reviews (PROSPERO), under number CRD42016045594 30. However, the criteria "g" had to be defined after the start of the analysis, because different methodological types should not be analyzed together, and the cohort study has more scientific evidence.

Two independent researchers evaluated the titles and abstracts of the articles obtained. Then, all potentially eligible publications were selected for full reading. Data extraction and final classification for inclusion in the meta-analysis were also performed independently, comparing the results subsequently, and a consensus was reached by discussion. 
Table 1

Details of the search strategy for the PubMed database.

\begin{tabular}{|c|c|}
\hline Strategy & Terms searched \\
\hline 1 & $\begin{array}{c}\text { (advanced[All Fields] AND ("maternal age"[MeSH Terms] OR ("maternal”[All Fields] AND "age"[All Fields]) OR "maternal age"[All Fields]) } \\
\text { AND ("pregnancy outcome"[MeSH Terms] OR ("pregnancy"[All Fields] AND “outcome"[All Fields]) OR "pregnancy outcome"[All Fields])) AND } \\
\text { ("2005/01/01"[PDAT] : "2015/12/31"[PDAT]) }\end{array}$ \\
\hline 2 & $\begin{array}{c}\text { (advanced[All Fields] AND ("maternal age"[MeSH Terms] OR (“maternal”[All Fields] AND “age"[All Fields]) OR "maternal age”[All Fields]) } \\
\text { AND adverse[All Fields] AND ("mothers"[MeSH Terms] OR “mothers"[All Fields] OR “maternal"[All Fields]) AND outcome[All Fields]) AND } \\
\text { (“2005/01/01"[PDAT] : “2015/12/31"[PDAT]) }\end{array}$ \\
\hline 3 & $\begin{array}{c}\text { (advanced[All Fields] AND ("maternal age"[MeSH Terms] OR ("maternal”[All Fields] AND "age"[All Fields]) OR "maternal age"[All Fields]) } \\
\text { AND ("mothers"[MeSH Terms] OR "mothers"[All Fields] OR "maternal”[All Fields]) AND ("complications"[Subheading] OR “complications"[All } \\
\text { Fields])) AND (“2005/01/01"[PDAT] : “201512/31"[PDAT]) }\end{array}$ \\
\hline 4 & 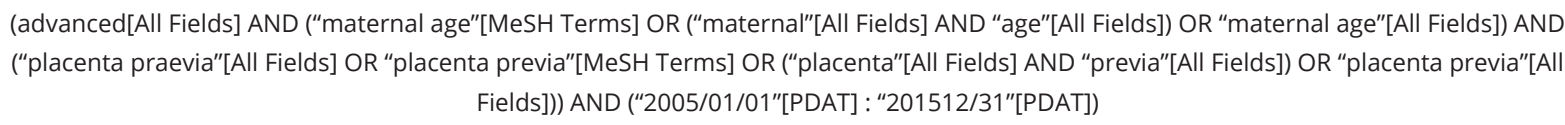 \\
\hline 5 & 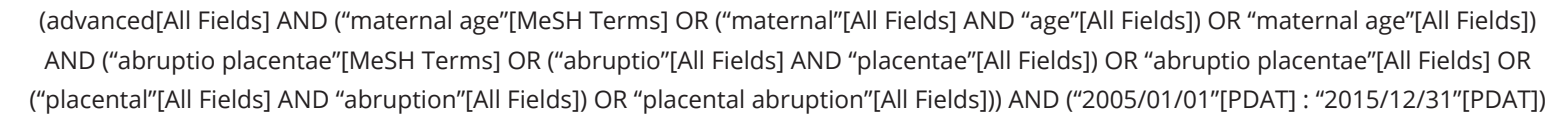 \\
\hline
\end{tabular}

The authors collected the main information of each article by the data extraction form, which included the complete reference of the article (authors, title, periodical, year of publication), study location, sample size, study design, participant characteristics, outcomes of interest, confounding factors used in the adjustment, and any explanations for the results.

After collecting the information, the authors evaluated the methodological quality according to the Newcastle-Ottawa Scale (NOS) 31. In this scale, the maximum number of stars for each item is: four for selection, two for comparability, and three for outcome, with the highest quality being represented by nine stars. Any divergences were also resolved by discussion. Only articles with seven or more stars were chosen to compose the meta-analysis, since they present satisfactory methodological quality.

For the data summary, we used Stata 12.0 (StataCorp LP, College Station, USA). To measure inconsistency among the studies (percentage of total variation among studies because of heterogeneity), we used the I2 statistic proposed by Higgins et al. 32 , with a $95 \%$ confidence interval $(95 \% \mathrm{CI})$ for the odds ratio (OR) of PP and PA, according to maternal age. The heterogeneity of the synthesis estimates was explored according to prespecified subgroups. The meta-regression model was used to investigate possible covariates that contributed to the very important heterogeneity among the studies, and only those with p-value $<0.05$ remained in the final model. The following covariables were analyzed: (1) stratification of age group of AMA women; (2) parity; (3) study with adjusted OR analysis by previous caesarean section or previous PP for the studies with PP outcome, and hypertensive diseases, smoking, and diabetes for the studies with PA outcome; (4) exclusion of multiple gestation in sample selection or adjustment during analysis; (5) methodological quality of the studies. Publication bias was explored using funnel plot and Egger's test if there were at least ten eligible studies included in the meta-analysis.

\section{Results}

After excluding 1,330 articles by the titles and abstracts, we identified 150 potentially eligible articles for inclusion in this meta-analysis, as follows: 142 using the search strategy in the databases and eight by manual search. Of these, 127 did not meet the inclusion criteria previously determined, and were subsequently excluded, as shown in Figure 1. Twenty-three articles met the inclusion criteria and were included in the meta-analysis. According to the NOS, most studies had a high methodological 
Figure 1

Flowchart of the selection process of articles included in the meta-analysis on the risk of placenta praevia and placental abruption in women with advanced maternal age.

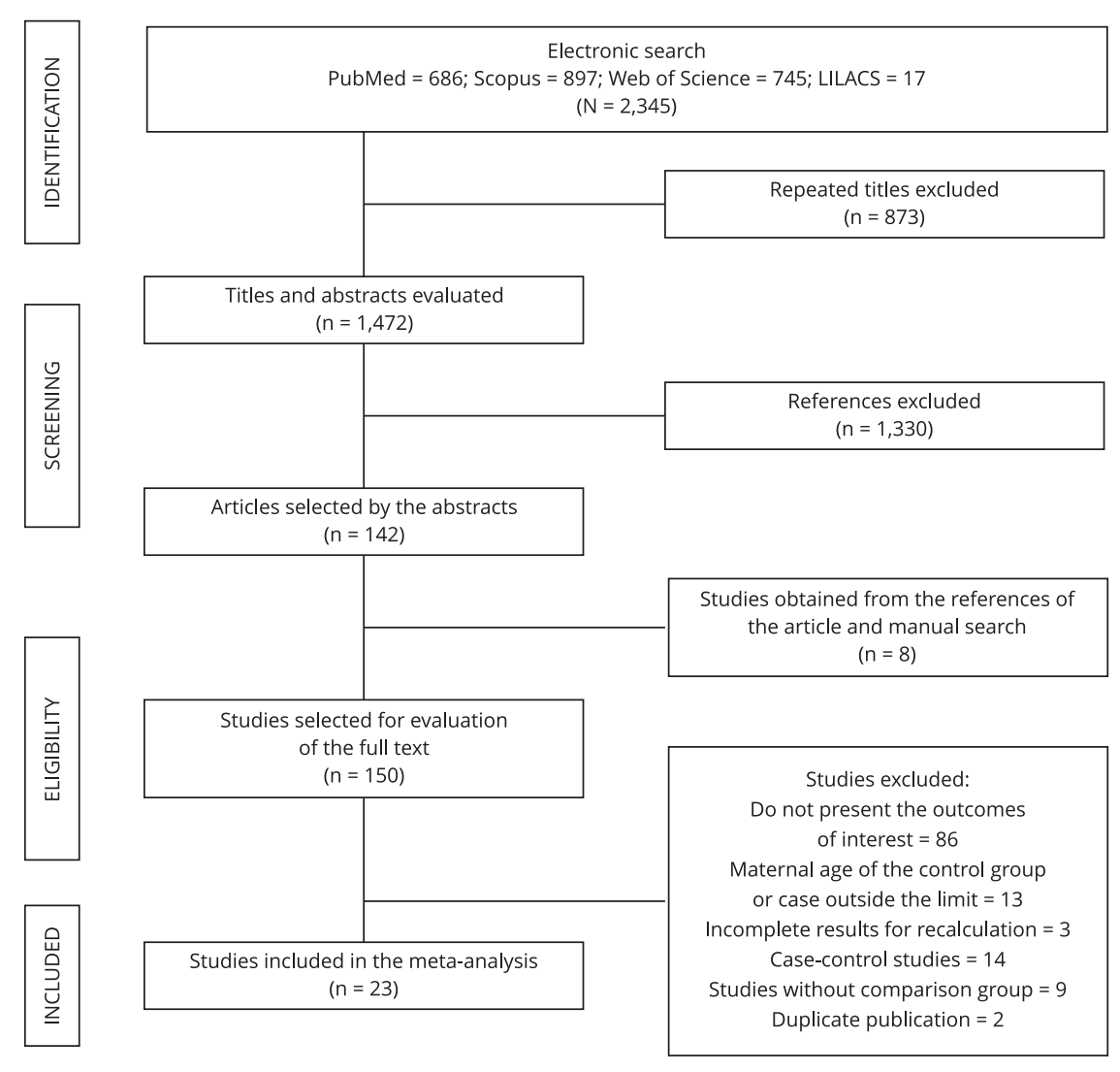

quality. Of the 23 studies, seven received seven stars (30.4\%), eleven received eight stars (47.8\%), and five received nine stars (21.7\%). More than $80 \%$ of the studies had a sample above 5,000 women.

The studies varied widely regarding the categorization of maternal age and parity. We considered 35 years or older as the cutoff point for separation between young and older women. Most articles subdivided advanced maternal age into 35-39 years and $\geq 40$ years 10,11,12,13,14,15,16,19,20,33,34,35, others used $\geq 35$ years $21,25,36,37,38,39,40$, and some only considered AMA age $\geq 40$ years 41,42,43,44. Regarding the definition of the age range for the comparison group, the studies were very different, with most using 20 to 34 years (30.4\%), followed by < 35 years (21.1\%), 25 to 29 years (17.4\%), and others (26.1\%). Studies have also shown different results when examining PP and PA among nulliparous or multiparous women, or in the combination of both groups, as can be seen in Table 2.

Because the studies differ in the mixes of participants, in defining outcomes, among other reasons, we used the random effects model in all analyses to calculate the weighted mean OR. Additionally, to make the subgroup analysis with a coherent age group, the studies that presented a classification of $A M A \geq 35$ years were included in the classification of 35-39 years, since in studies that subdivide AMA, at least $80 \%$ of women are in the 35-39 age group 10,11,13,15,16,19,20,33,34,35.

Very important heterogeneity was found for studies with PP outcome ( $p<0.001$, I2 $=97.9 \%$ ). In the analysis of subgroups by age group, there was no reduction in heterogeneity, but one can see that, as age increases, the chance of occurrence of PP also increases, OR = 2.7 (95\%CI: 2.3-3.1) in studies 


\section{Table 2}

Characteristics of the studies on the association of placenta praevia (PP) and placental abruption (PA) with advanced maternal age (AMA) selected for inclusion in the meta-analysis, 2005 to 2015.

\begin{tabular}{|c|c|c|c|c|c|c|c|}
\hline $\begin{array}{l}\text { Study reference for age range of } \\
\text { the AMA group }\end{array}$ & $\begin{array}{l}\text { Age range of } \\
\text { the control } \\
\text { group (years) }\end{array}$ & Outcome & Parity & $\begin{array}{l}\text { Excludes } \\
\text { multiple } \\
\text { gestation }\end{array}$ & Total sample & $\begin{array}{l}\text { Adjusted } \\
\text { OR * }\end{array}$ & Location \\
\hline \multicolumn{8}{|l|}{$\geq 35$ years } \\
\hline Lamminpää et al. 39 (2015) & $<35$ & PP & WPS & Yes & 249,648 & No & Finland \\
\hline Lao et al. 40 (2014) & $20-34$ & PP & WPS & Yes & 64,886 & No & China \\
\hline Pawde et al. 21 (2015) & $<35$ & $\mathrm{PP}$ and PA & WPS & No & 679 & No & India \\
\hline Alshami et al. 36 (2011) & $20-34$ & $\mathrm{PP}$ and $\mathrm{PA}$ & $\mathrm{N}$ & Yes & 888 & No & UAE \\
\hline Biro et al. 37 (2012) & $<35$ & $\mathrm{PP}$ and PA & $\mathrm{N}$ and $\mathrm{M}$ & No & 133,357 & No & Australia \\
\hline Hung et al. 38 (2007) & $20-34$ & PA & WPS & Yes & 36,989 & Yes & Taiwan \\
\hline Wang et al. 25 (2011) & $<35$ & PA & $\mathrm{N}$ and $\mathrm{M}$ & Yes & 6,619 & No & Norway \\
\hline \multicolumn{8}{|l|}{$35-39$ and $\geq 40$ years } \\
\hline Bateman \& Simpson 15 (2006) & $20-34$ & $\mathrm{PP}$ and PA & WPS & No & $5,163,887$ & No & USA \\
\hline Cleary-Goldman et al. ${ }^{11}$ (2005) & $<35$ & $\mathrm{PP}$ and PA & WPS & Yes & 36,056 & No & USA \\
\hline Grotegut et al. 12 (2014) & $<35$ & $\mathrm{PP}$ and PA & WPS & Yes & $12,628,746$ & Yes & USA \\
\hline Hung et al. 34 (2007) & $20-34$ & PP & WPS & Yes & 37,445 & Yes & Taiwan \\
\hline Joseph et al. 13 (2005) & $20-24$ & $\mathrm{PP}$ and $\mathrm{PA}$ & WPS & Yes & 51,084 & No & Canada \\
\hline Liu \& Zhang 16 (2014) & $25-29$ & $\mathrm{PP}$ and $\mathrm{PA}$ & WPS & No & 57,555 & No & China \\
\hline Matsuda et al. 14 (2011) & $20-34$ & $\mathrm{PP}$ and $\mathrm{PA}$ & WPS & Yes & 3,749 & Yes & Japan \\
\hline Dietl et al. 19 (2015) & $<30$ & PP & WPS & Yes & 5,399 & No & Germany \\
\hline Blomberg et al. 10 (2014) & $25-29$ & $\mathrm{PP}$ and PA & $\mathrm{N}$ & Yes & 374,619 & No & Sweden \\
\hline Carolan et al. 33 (2011) & $25-29$ & PP & $\mathrm{N}$ & No & 25,997 & No & Australia \\
\hline Ludford et al. 20 (2012) & $25-29$ & $\mathrm{PP}$ and PA & $\mathrm{N}$ & Yes & 34,695 & No & Australia \\
\hline Yang et al. 35 (2009) & $<20$ & $\mathrm{PP}$ and $\mathrm{PA}$ & $\mathrm{N}$ and $\mathrm{M}$ & Yes & $1,815,843$ & Yes & USA \\
\hline \multicolumn{8}{|l|}{$\geq 40$ years } \\
\hline Carolan et al. 41 (2013) & $30-34$ & PP & WPS & No & 49,126 & No & Australia \\
\hline $\begin{array}{l}\text { Chawanpaiboon \& Hengrasmee } 42 \\
\text { (2013) }\end{array}$ & $20-29$ & $\mathrm{PP}$ and PA & WPS & No & 2,200 & No & Thailand \\
\hline Traisrisilp \& Tongsong 44 (2015) & $20-30$ & PP & WPS & Yes & 19,599 & No & Thailand \\
\hline Räisänen et al. 43 (2013) & $<20$ & PA & $\mathrm{N}$ and $\mathrm{M}$ & Yes & $1,162,126$ & Yes & Finland \\
\hline
\end{tabular}

M: multiparous; N: nulliparous; OR: odds ratio; WPS: without parity stratification.

* PP adjusted OR for previous cesarean delivery and prior PP; PA adjusted OR for hypertensive diseases, smoking, and diabetes.

that used the 35-39 age range; for the $\geq 40$ age range, the chance was 3.8 (95\%CI: 3.0-4.8), as shown in Figure 2a. When analyzing parity, heterogeneity remained important, but there was not statistically significant difference between nulliparous and multiparous groups regarding the chance of PP (Figure $2 \mathrm{~b}$ ). When conducting the same subgroup analysis only with the studies that had the OR adjusted for previous caesarean section and previous PP, the results followed the same direction as the studies included in this meta-analysis; however, they were shown to have a greater magnitude of association, but with ORs contained within the confidence interval of the measures shown (cf. Supplemental Material; http://cadernos.ensp.fiocruz.br/site/public_site/arquivo/csp-2061-16-suppl_4803.pdf).

When performing the meta-regression, the covariables age group, parity, and exclusion of multiple gestation explained around 63\% of the heterogeneity initially observed among the studies. Furthermore, we observed that studies reporting data with maternal age greater than or equal to 40 years old had a chance $46 \%$ higher of PP than the studies analyzing the age group of 35-39 years old (Table 3 ).

Very important heterogeneity was also verified for studies with PA outcome ( $<<0.001, \mathrm{I} 2=92 \%)$. Although heterogeneity decreased in the subgroup analysis, it remains substantial, and it is possible to 
Figure 2

Combined analysis of the odds ratio of placenta praevia among women according to age range and parity.

2a) Age range

OR $(95 \% \mathrm{Cl}) \quad$ Weight $(\%)$

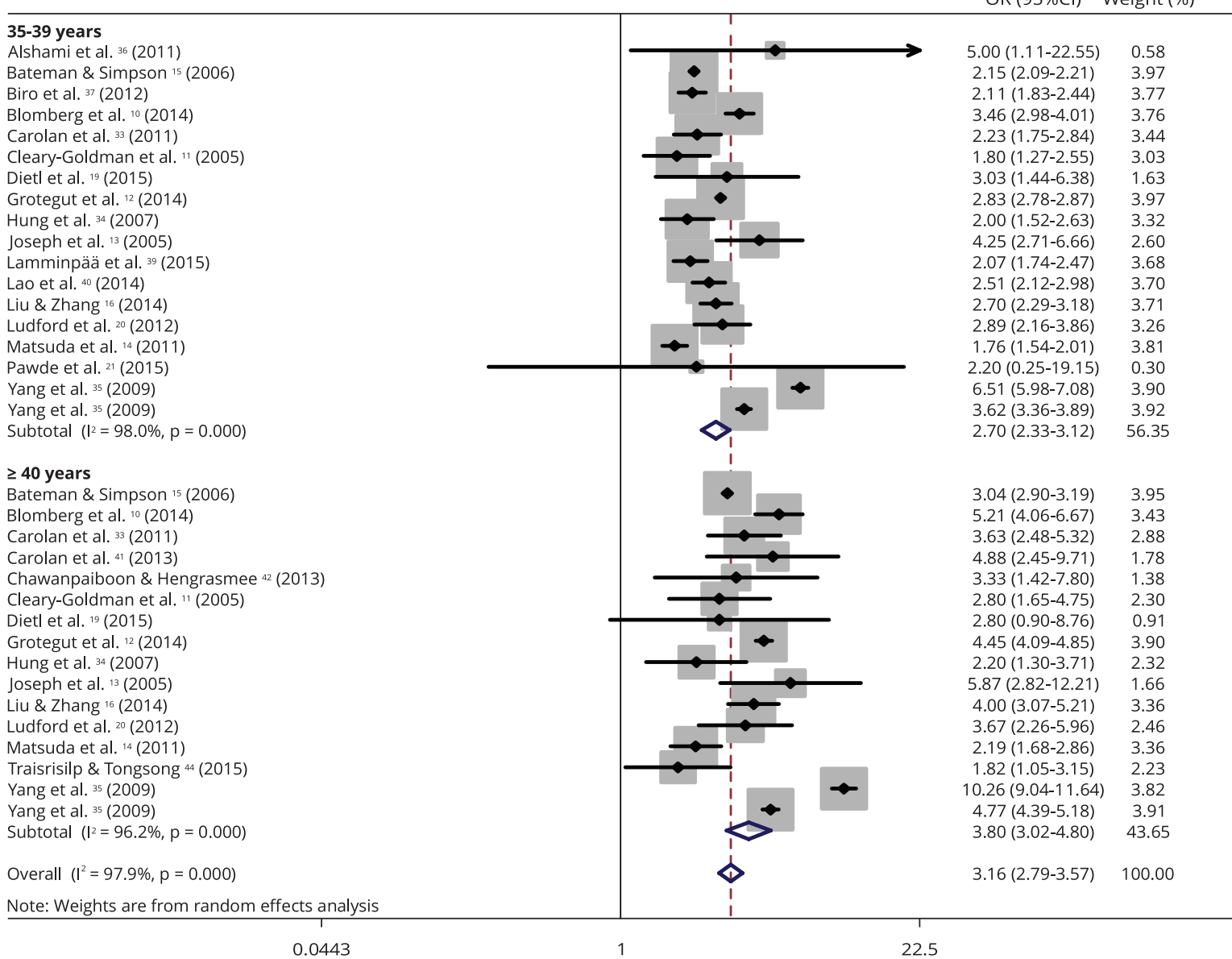

(continues)

observe that the chance of this outcome increases as the age group increases, with $\mathrm{OR}=1.3(95 \% \mathrm{CI}$ : 1.2-1.4) and $\mathrm{OR}=1.7$ (95\%CI: $1.5-1.9$ ) for 35-39 years and $\geq 40$ years, respectively (Figure 3 ). When conducting the same subgroup analysis with only studies that had the odds ratio adjusted for hypertensive diseases, smoking, and diabetes, the results followed the same direction as the studies included in this meta-analysis; however, they showed a slightly smaller magnitude of association, but still contained within the confidence interval of the measures shown (cf. Supplemental Material; http:// http://cadernos.ensp.fiocruz.br/site/public_site/arquivo/csp-2061-16-suppl_4803.pdf).

When performing the meta-regression, we observed that the studies reporting data with maternal age greater than or equal to 40 years had a chance $25 \%$ higher of PA than the studies analyzing the age group of 35-39 years. Moreover, it is suggested that age stratification and parity explained $69.7 \%$ of the heterogeneity initially observed in the studies (Table 3).

All twenty-three studies included in the meta-analyses were also included in the publication bias analyses; 20 studies addressed PP and 16 studies addressed PA. After the qualitative analysis of the funnel plot, we performed a Egger's test, which detected evidence of publication bias for PA 
2b) Parity

\begin{tabular}{|c|c|c|}
\hline 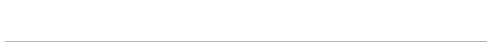 & OR $(95 \% \mathrm{Cl})$ & Weight (\%) \\
\hline $\begin{array}{l}\text { Without parity specification } \\
\text { Bateman \& Simpson }{ }^{15}(2006) \\
\text { Bateman \& Simpson }{ }^{15}(2006) \\
\text { Carolan et al. }{ }^{41}(2013) \\
\text { Chawanpaiboon \& Hengrasmee }{ }^{42}(2013) \\
\text { Cleary-Goldman et al. }{ }^{11}(2005) \\
\text { Cleary-Goldman et al. }{ }^{11}(2005) \\
\text { Dietl et al. }{ }^{19}(2015) \\
\text { Dietl et al. }{ }^{19}(2015) \\
\text { Grotegut et al. }{ }^{12}(2014) \\
\text { Grotegut et al. }{ }^{12}(2014) \\
\text { Hung et al. }{ }^{44}(2007) \\
\text { Hung et al. }{ }^{44}(2007) \\
\text { Joseph et al. }{ }^{13}(2005) \\
\text { Joseph et al. }{ }^{13}(2005) \\
\text { Lamminpää et al. }{ }^{39}(2015) \\
\text { Lao et al. }{ }^{40}(2014) \\
\text { Liu \& Zhang }{ }^{16}(2014) \\
\text { Liu \& Zhang }{ }^{16}(2014) \\
\text { Matsuda et al. }{ }^{14}(2011) \\
\text { Matsuda et al. }{ }^{14}(2011) \\
\text { Pawde et al. }{ }^{21}(2015) \\
\text { Traisrisilp \& Tongsong }{ }^{44}(2015) \\
\text { Subtotal }(12=96.0 \%, p=0.000)\end{array}$ & $\begin{array}{l}3.04(2.90-3.19) \\
2.15(2.09-2.21) \\
4.88(2.45-9.71) \\
3.33(1.42-7.80) \\
1.80(1.27-2.55) \\
2.80(1.65-4.75) \\
3.03(1.44-6.38) \\
2.80(0.90-8.76) \\
2.83(2.78-2.87) \\
4.45(4.09-4.85) \\
2.00(1.52-2.63) \\
2.20(1.30-3.71) \\
4.25(2.71-6.66) \\
5.87(2.82-12.21) \\
2.07(1.74-2.47) \\
2.51(2.12-2.98) \\
2.70(2.29-3.18) \\
4.00(3.07-5.21) \\
2.19(1.68-2.86) \\
1.76(1.54-2.01) \\
2.20(0.25-19.15) \\
1.82(1.05-3.15) \\
2.66(2.38-2.98)\end{array}$ & $\begin{array}{l}3.95 \\
3.97 \\
1.78 \\
1.38 \\
3.03 \\
2.30 \\
1.63 \\
0.91 \\
3.97 \\
3.90 \\
3.32 \\
2.32 \\
2.60 \\
1.66 \\
3.68 \\
3.70 \\
3.71 \\
3.36 \\
3.36 \\
3.81 \\
0.30 \\
2.23 \\
60.87\end{array}$ \\
\hline $\begin{array}{l}\text { Nulliparous } \\
\text { Alshami et al. }{ }^{36}(2011) \\
\text { Blomberg et al. }{ }^{10}(2014) \\
\text { Blomberg et al. }{ }^{10}(2014) \\
\text { Carolan et al. }{ }^{33}(2011) \\
\text { Carolan et al. }{ }^{33}(2011) \\
\text { Ludford et al. }{ }^{20}(2012) \\
\text { Ludford et al. }{ }^{20}(2012) \\
\text { Yang et al. }{ }^{35}(2009) \\
\text { Yang et al. }{ }^{35}(2009) \\
\text { Subtotal }\left({ }^{2}=96.4 \%, p=0.000\right)\end{array}$ & $\begin{array}{c}5.00(1.11-22.55) \\
3.46(2.98-4.01) \\
5.21(4.06-6.67) \\
3.63(2.48-5.32) \\
2.23(1.75-2.84) \\
3.67(2.26-5.96) \\
2.89(2.16-3.86) \\
6.51(5.98-7.08) \\
10.26(9.04-11.64) \\
4.31(3.01-6.16)\end{array}$ & $\begin{array}{c}0.58 \\
3.76 \\
3.43 \\
2.88 \\
3.44 \\
2.46 \\
3.26 \\
3.90 \\
3.82 \\
27.53\end{array}$ \\
\hline $\begin{array}{l}\text { Multiparous } \\
\text { Biro et al. }{ }^{37}(2012) \\
\text { Yang et al. }{ }^{35}(2009) \\
\text { Yang et al. }{ }^{35}(2009) \\
\text { Subtotal }\left(\left.\right|^{2}=97.9 \%, p=0.000\right)\end{array}$ & $\begin{array}{l}2.11(1.83-2.44) \\
3.62(3.36-3.89) \\
4.77(4.39-5.18) \\
3.33(2.29-4.84)\end{array}$ & $\begin{array}{c}3.77 \\
3.92 \\
3.91 \\
11.60\end{array}$ \\
\hline $\begin{array}{l}\text { Overall }\left(l^{2}=97.9 \%, p=0.000\right) \\
\text { Note: Weights are from random effects analysis }\end{array}$ & $3.16(2.79-3.57)$ & 100.00 \\
\hline
\end{tabular}

95\% Cl: 95\% confidence interval; OR: odds ratio.

Test of difference between subgroups: age range $(p=0.023)$ and parity $(p=0.064)$.

(coefficient $=1.60, \mathrm{p}=0.035$ ), but not for PP (coefficient $=1.74, \mathrm{p}=0.228$ ). Because of the substantial heterogeneity, the "trim and fill" method was not performed because it was not recommended in this situation.

Our review provided very low-quality evidence for both outcomes, since it encompasses observational studies with high statistical heterogeneity, diversity of populations, no control of confounding factors in several cases, and publication bias. However, the confidence intervals were small and there is a dose-response gradient, as well as a large magnitude of effect for PP.

\section{Discussion}

For both outcomes, with increasing age, the magnitude of the association strength also increased, and PP was more strongly associated with AMA than PA. For parity, there was no difference between nulliparous and multiparous women considered older for both PP and PA. The significant heterogeneity among the studies can be explained in part by age stratification, parity classification (nulliparous, mul- 
Figure 3

Combined analysis of the odds ratio of placental abruption among women according to age range and parity.

3a) Age range

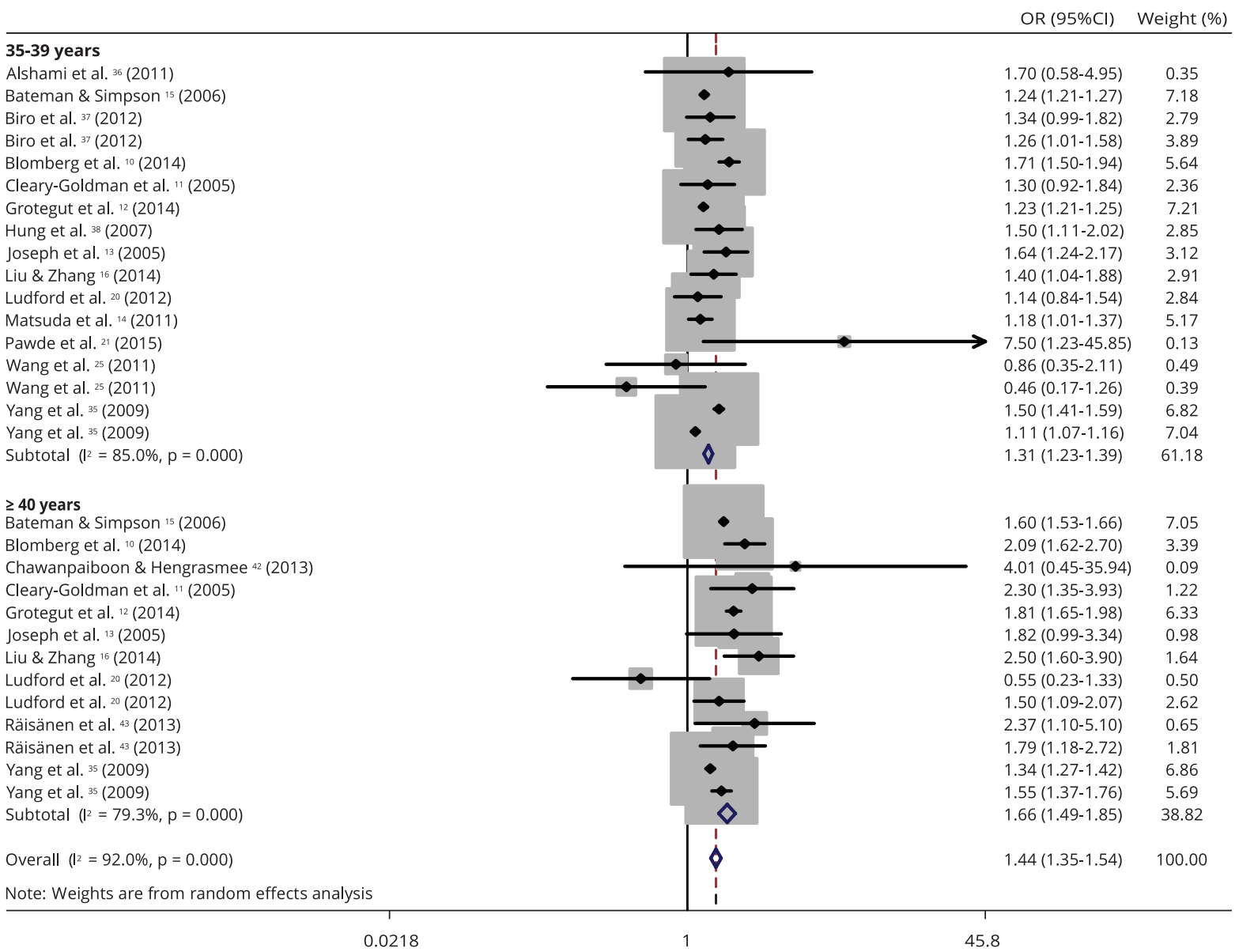

(continues)

tiparous, and without parity stratification), control of exclusion of multiple gestation during statistical analyses, and specific characteristics of the population.

The magnitude of the association increases in the same direction as the age range for PP; this can be partially explained by atherosclerotic changes in the blood vessels of the uterus, causing impairment of uteroplacental blood flow 26 and infarction that causes little perfusion of the placenta 45 . Consequently, the placenta is implanted in the lower uterine segment, thereby increasing the risk of PP 46.

In the association between PP and AMA, according to parity, one can see that the nulliparous women considered older had no difference for the PP outcome compared to the multiparous considered older. For both, the OR was $>3.00$, showing that this outcome is important not only clinically, but also for public health, since the number of women who are delaying pregnancy is constantly increasing, which will lead to antenatal admissions in hospitals because of complications and caesarean deliveries for PP 37.

In this meta-analysis, studies with OR adjusted to previous c-section and previous PP showed a greater magnitude of association with PP (35-39 years, OR = 3.08, 95\%CI: 2.26-4.19; $\geq 40$ years, OR = 
OR $(95 \%$ Cl) $\quad$ Weight $(\%)$

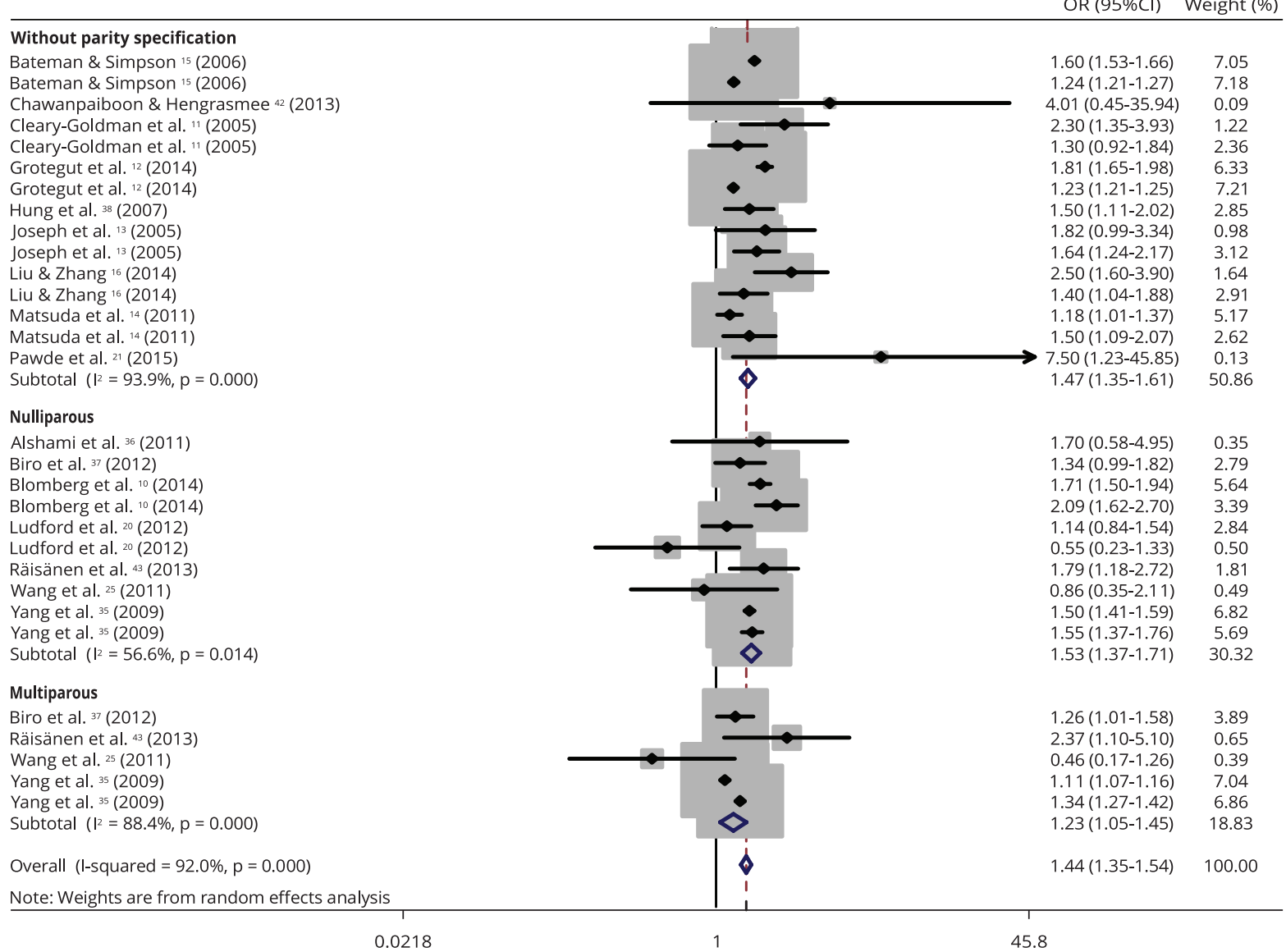

95\% Cl: 95\% confidence interval; OR: odds ratio.

Test of difference between subgroups: age range $(p=0.005)$ and parity $(p=0.194)$.

4.36, 95\%CI: 3.08-6.17) compared to those that were not adjusted. This finding shows that, when logistic regression is made and adjusted for important factors, one gets closer to the actual contribution of old age to the outcome of PP. In Sweden 10 and the United States 35, considering nulliparous women, the ORs increased for AMA when controlling confounding factors. For women $\geq 40$ years old, the OR changed from 5.0 to 5.2 in Sweden 10 and from 9.7 to 10.3 in the United States, with all values being statistically significant 35 .

Again, one can see the effect of advanced age on the outcome, since the magnitude of the association with PA increases as the age range increases. This is likely due to decreased uterine blood flow, uteroplacental hypoperfusion, and major placental infarctions, leading to hemorrhagic disorders in older women 46. Although the magnitude of association between AMA and PA is lower than for PP, it is also important to clarify this relationship, since between $1 \%$ and $2 \%$ of women of advanced maternal age develop this outcome 11,12,15,35,38. Overall, PA is more likely to be affected by risk factors occurring during pregnancy 35 , so health professionals must pay attention to signs suggesting PA that a woman may present during prenatal care.

Although several studies on PA did not control important confounding factors such as: high blood pressure, tobacco/alcohol use, diabetes, childbirth payment source, education level, body mass index, 
Table 3

Univariate and multiple meta-regression models.

\begin{tabular}{|c|c|c|c|c|c|c|c|}
\hline \multirow[t]{2}{*}{ Variables } & \multicolumn{4}{|c|}{ Univariate meta-regression models } & \multicolumn{3}{|c|}{ Multiple meta-regression models } \\
\hline & Adjusted R2 (\%) & OR & $95 \% \mathrm{Cl}$ & p-value & OR & $95 \% \mathrm{Cl}$ & p-value \\
\hline PP & & & & & & ted $R^{2}=63 . C$ & \\
\hline \multicolumn{8}{|l|}{ Age group (years) } \\
\hline $35-39$ & \multirow{2}{*}{16.6} & 1.00 & - & & 1.00 & - & \\
\hline$\geq 40$ & & 1.41 & $1.05-1.90$ & 0.023 & 1.46 & $1.18-1.81$ & 0.001 \\
\hline \multicolumn{8}{|l|}{ Parity } \\
\hline Without parity stratification & \multirow{3}{*}{21.3} & 1.00 & - & & 1.00 & - & \\
\hline Nulliparous & & 1.60 & $1.15-2.23$ & 0.007 & 1.53 & $1.20-1.97$ & 0.001 \\
\hline Multiparous & & 1.23 & $0.77-1.96$ & 0.375 & 1.26 & $0.90-1.74$ & 0.168 \\
\hline \multicolumn{8}{|l|}{ Study with adjusted OR * } \\
\hline No & \multirow{2}{*}{8.8} & 1.00 & - & & - & - & \\
\hline Yes & & 1.28 & $0.94-1.75$ & 0.109 & - & - & - \\
\hline \multicolumn{8}{|l|}{ Exclusion of multiple gestation } \\
\hline No & \multirow{2}{*}{20.0} & 1.00 & - & & 1.00 & - & \\
\hline Yes & & 1.47 & $1.08-1.99$ & 0.015 & 1.44 & $1.15-1.81$ & 0.003 \\
\hline \multicolumn{8}{|c|}{ Methodological quality of the studies } \\
\hline 7 stars & \multirow{2}{*}{11.9} & 1.00 & - & & - & - & \\
\hline 8-9 stars & & 0.73 & $0.54-1.00$ & 0.05 & - & - & - \\
\hline PA & & & & & & ted $R^{2}=69.7$ & \\
\hline \multicolumn{8}{|l|}{ Age group (years) } \\
\hline $35-39$ & \multirow{2}{*}{36.7} & 1.00 & - & & 1.00 & & \\
\hline$\geq 40$ & & 1.26 & $1.07-1.48$ & 0.005 & 1.25 & $1.10-1.43$ & 0.001 \\
\hline \multicolumn{8}{|l|}{ Parity } \\
\hline Without parity stratification & \multirow{3}{*}{13.9} & 1.21 & $0.94-1.55$ & 0.122 & 1.19 & $1.01-1.40$ & 0.040 \\
\hline Nulliparous & & 1.23 & $0.94-1.60$ & 0.123 & 1.27 & $1.06-1.53$ & 0.012 \\
\hline Multiparous & & 1.00 & - & & 1.00 & - & - \\
\hline \multicolumn{8}{|l|}{ Study with adjusted OR * } \\
\hline No & \multirow{2}{*}{0.00} & 1.00 & - & & - & - & \\
\hline Yes & & 0.95 & $0.78-1.15$ & 0.605 & - & - & - \\
\hline \multicolumn{8}{|l|}{ Exclusion of multiple gestation } \\
\hline No & \multirow{2}{*}{0.00} & 1.00 & - & & - & - & \\
\hline Yes & & 1.04 & $0.85-1.28$ & 0.685 & - & - & - \\
\hline \multicolumn{8}{|c|}{ Methodological quality of the studies } \\
\hline 7 stars & \multirow{2}{*}{4.05} & 1.00 & - & & - & - & \\
\hline 8-9 stars & & 0.88 & $0.73-1.06$ & 0.183 & - & - & - \\
\hline
\end{tabular}

95\%Cl: 95\% confidence interval; OR: odds ratio; PA: placental abruption; PP: placenta praevia.

* By previous caesarean section or PP for the studies with PP outcome, and hypertensive diseases, smoking, and diabetes for the studies with PA outcome.

socioeconomic classification, prior abortion, and anemia, the chances found were very close to the measures found in studies that adjusted OR for hypertensive diseases, smoking, and diabetes (35-39 years, $\mathrm{OR}=1.27,95 \% \mathrm{CI}: 1.14-1.41 ; \geq 40$ years, $\mathrm{OR}=1.59,95 \% \mathrm{CI}: 1.35-1.87$ ).

Although the technological advancement of medicine helps in the diagnosis of PP and PA, clinical diagnosis is still extremely relevant. Thus, it is important for practitioners responsible for prenatal monitoring to be able to diagnose such complications in a timely manner, monitor maternal condition in the search for the best prognosis, and identify women who are more likely to develop PP and PA, since perinatal mortality is determined by the severity of placental abruption and the gestational age at which it occurs, and postpartum hemorrhaging may be a consequence of PP 29,47. 
This study presents the following strengths: using broad terms related to the outcomes to search the database, thus also including studies not statistically significant; using adjustment factors that are important in the analysis; and analyzing the subgroups of age ranges and parity separately, thus providing a greater number of studies and a more detailed analysis of the relationship between AMA and PP/PA. However, there are limitations that must be considered when interpreting the results, such as: not having used the EMBASE database, which has a slightly larger scope than Scopus, although they belong to the same editorial group; using a quality assessment scale that also penalizes methodological problems of differing degrees, although this is one of the main scales used to assess cohort studies; excluding case-control studies, since they cannot be analyzed together with cohort studies; and not including only studies with adjusted analyses, because this would greatly reduce the number of studies in each group and reduce the number of studies in some subgroups.

It is important that future studies control the confounding factors between maternal age and PP and PA by the following cofactors: previous abortion; hypertensive diseases; previous c-section; diabetes; previous PP; education level; parity; multiple gestation; premature rupture of membranes; use of assisted reproduction; use of tobacco, alcohol, and/or drugs, so that the studies show less heterogeneity and the combined measures present a higher level of confidence. However, studies that used only hypertensive diseases, diabetes, smoking, previous c-section, previous PP - which are important confounding factors in the analysis -, found association of advanced maternal age with PP and PA $12,14,34,35,38,43$.

In addition to confounding factors, other characteristics, such as diagnostic methods to discover outcomes, exact definition used for PP and PA (because of the different types), better standardization of comparison groups, and different clinical scenarios that involve the emergency conditions related to PP and PA, are important to be defined for greater homogeneity among the studies. Thus, the quality of the evidence, for both outcomes, may improve by the reduction of statistical heterogeneity, greater homogeneity among populations, control of important confounding factors, and no publication bias.

Although the review provided very low-quality evidence for both outcomes, the results suggest an association between AMA and PP and between AMA and PA. We also found that AMA is more strongly associated with PP than with PA. Nonetheless, this study highlights the relevance of improving and standardizing the studies in search of an association between AMA and complications in pregnancy, such as PP and PA, since there is a growing number of women who have been postponing maternity in the world. These outcomes are unfavorable to women's and children's health and affect health services by requiring more complex care. In this regard, early diagnosis of cases and appropriate treatment should be offered by health teams to pregnant women with AMA.

\section{Contributors}

K. G. Martinelli participated in developing the study concept and in all stages of the production of this article. She was responsible for the final version submitted for publication. E. M. Garcia participated in the data analysis and interpretation in the and approval of the final version for publication. E. T. Santos Neto and S. G. N. Gama participated in developing the study concept, in the critical review of the intellectual content, and in the approval of the final version. 


\section{References}

1. Bayrampour H, Heaman M. Advanced maternal age and the risk of cesarean birth: a systematic review. Birth 2010; 37:219-26.

2. Kirz DS, Dorchester W, Freeman RK. Advanced maternal age: the mature gravida. Am J Obstet Gynecol 1985; 152:7-12.

3. Schimmel MS, Bromiker R, Hammerman C, Chertman L, Ioscovich A, Granovsky-Grisaru $\mathrm{S}$, et al. The effects of maternal age and parity on maternal and neonatal outcome. Arch Gynecol Obstet 2015; 291:793-8.

4. Olusanya BO, Solanke OA. Perinatal correlates of delayed childbearing in a developing country. Arch Gynecol Obstet 2012; 285:951-7.

5. Diejomaoh MFE, Al-Shamali IA, Al-Kandari F, Al-Qenae M, Mohd AT. The reproductive performance of women at 40 years and over. Eur J Obstet Gynecol Reprod Biol 2006; 126:33-8.

6. Nojomi M, Haghighi L, Bijari B, Rezvani L, Tabatabaee SK. Delayed childbearing: pregnancy and maternal outcomes. Iran J Reprod Med 2010; 8:80-5.

7. Tabcharoen C, Pinjaroen S, Suwanrath C, Krisanapan O. Pregnancy outcome after age 40 and risk of low birth weight. J Obstet Gynaecol 2009; 29:378-83.

8. Bayrampour H, Heaman M, Duncan KA, Tough S. Comparison of perception of pregnancy risk of nulliparous women of advanced maternal age and younger age. J Midwifery Womens Health 2012; 57:445-53.

9. Başer E, Seçkin KD, Erkilinç S, Karsli MF, Yeral IM, Kaymak O, et al. The impact of parity on perinatal outcomes in pregnancies complicated by advanced maternal age. J Turk Ger Gynecol Assoc 2013; 14:205-9.

10. Blomberg M, Tyrberg RB, Kjølhede P. Impact of maternal age on obstetric and neonatal outcome with emphasis on primiparous adolescents and older women: a Swedish Medical Birth Register Study. BMJ Open 2014; 4:e005840.

11. Cleary-Goldman J, Malone FD, Vidaver J, Ball $\mathrm{RH}$, Nyberg DA, Comstock CH, et al. Impact of maternal age on obstetric outcome. Obstet Gynecol 2005; 105(5 Part 1):983-90.

12. Grotegut CA, Chisholm CA, Johnson LNC, Brown HL, Heine RP, James AH. Medical and obstetric complications among pregnant women aged 45 and older. PLoS One 2014; 9:e96237.

13. Joseph KS, Allen AC, Dodds L, Turner LA, Scott H, Liston R. The perinatal effects of delayed childbearing. Obstet Gynecol 2005; 105:1410-8.

14. Matsuda Y, Kawamichi Y, Hayashi K, Shiozaki A, Satoh S, Saito S. Impact of maternal age on the incidence of obstetrical complications in Japan: maternal age and obstetric complications. J Obstet Gynaecol Res 2011; 37:1409-14.
15. Bateman BT, Simpson LL. Higher rate of stillbirth at the extremes of reproductive age: a large nationwide sample of deliveries in the United States. Am J Obstet Gynecol 2006; 194:840-5.

16. Liu X, Zhang W. Effect of maternal age on pregnancy: a retrospective cohort study. Chin Med J (Engl) 2014; 127:2241-6.

17. Balestena Sánchez JM, Pereda Serrano Y, Milán Soler JR. La edad materna avanzada como elemento favorecedor de complicaciones obstétricas y del nacimiento. Rev Cienc Med Pinar Rio 2015; 19:789-802.

18. Ciancimino L, Laganà $\mathrm{AS}$, Chiofalo $\mathrm{B}$, Granese $\mathrm{R}$, Grasso R, Triolo O. Would it be too late? A retrospective case-control analysis to evaluate maternal-fetal outcomes in advanced maternal age. Arch Gynecol Obstet 2014; 290:1109-14.

19. Dietl A, Cupisti S, Beckmann M, Schwab M, Zollner U. Pregnancy and obstetrical outcomes in women over 40 years of age. Geburtshilfe Frauenheilkd 2015; 75:827-32.

20. Ludford I, Scheil W, Tucker G, Grivell R. Pregnancy outcomes for nulliparous women of advanced maternal age in South Australia, 1998-2008. Aust N Z J Obstet Gynaecol 2012; 52:235-41.

21. Pawde AA, Kulkarni MP, Unni J. Pregnancy in women aged 35 years and above: a prospective observational study. J Obstet Gynecol India 2015; 65:93-6.

22. Peña Marti G, Barbato J, Betancourt C, Cala R, Douaihi H, Carvajal Marti A. Asociación entre prematuridad y embarazadas en edad avanzada. Rev Obstet Ginecol Venez 2007; 67:15-22.

23. Sanchez SE, Pacora PN, Farfan JH, Fernandez A, Qiu C, Ananth CV, et al. Risk factors of abruptio placentae among Peruvian women. Am J Obstet Gynecol 2006; 194:225-30.

24. Shaikh F, Wagan F, Jillani K, Memon K. Pregnancy outcome at maternal age 40 and older. Journal of the Liaquat University of Medical and Health Sciences 2012; 11:139-42.

25. Wang Y, Tanbo T, Åbyholm T, Henriksen T. The impact of advanced maternal age and parity on obstetric and perinatal outcomes in singleton gestations. Arch Gynecol Obstet 2011; 284:31-7.

26. Faiz AS, Ananth CV. Etiology and risk factors for placenta previa: an overview and metaanalysis of observational studies. J Matern Fetal Neonatal Med 2003; 13:175-90.

27. Ananth CV, Berkowitz GS, Savitz DA, Lapinski RH. Placental abruption and adverse perinatal outcomes. JAMA 1999; 282:1646-51.

28. Haeri S, Dildy GA. Maternal mortality from hemorrhage. Semin Perinatol 2012; 36:48-55.

29. Oyelese Y, Ananth CV. Placental abruption. Obstet Gynecol 2006; 108:1005-16. 
30. Martinelli KG, Santos Neto ET, Garcia EM Gama SGN. Advanced maternal age and risk of placenta previa and placental abruption: a systematic review and meta-analysis. PROSPERO 2016 CRD42016045594. http://www.crd. york.ac.uk/PROSPERO/display_record.asp? ID=CRD42016045594 (accessed on 18/Aug/ 2016).

31. Wells GA, Shea B, O'Connell D, Peterson J, Welch V, Losos M, et al. The Newcastle-Ottawa Scale (NOS) for assessing the quality of nonrandomised studies in meta-analyses. http://www.ohri.ca/programs/clinical_epi demiology/oxford.asp (accessed on 18/Aug/ 2016).

32. Higgins JPT, Thompson SG, Deeks JJ, Altman DG. Measuring inconsistency in meta-analyses. BMJ 2003; 327:557-60.

33. Carolan M, Davey M-A, Biro MA, Kealy M. Older maternal age and intervention in labor: a population-based study comparing older and younger first-time mothers in Victoria, Australia. Birth 2011; 38:24-9.

34. Hung TH, Hsieh CC, Hsu JJ, Chiu TH, Lo LM, Hsieh TT. Risk factors for placenta previa in an Asian population. Int J Gynaecol Obstet 2007; 97:26-30.

35. Yang Q, Wen S, Phillips K, Oppenheimer L, Black D, Walker M. Comparison of maternal risk factors between placental abruption and placenta previa. Am J Perinatol 2009; 26 : 279-86.

36. Alshami HA, Kadasne AR, Khalfan M, Iqbal SZ, Mirghani HM. Pregnancy outcome in late maternal age in a high-income developing country. Arch Gynecol Obstet 2011; 284:1113-6.

37. Biro MA, Davey M-A, Carolan M, Kealy M. Advanced maternal age and obstetric morbidity for women giving birth in Victoria, Australia: a population-based study. Aust $\mathrm{N} \mathrm{Z} \mathrm{J} \mathrm{Ob-}$ stet Gynaecol 2012; 52:229034.

38. Hung TH, Hsieh CC, Hsu JJ, Lo LM, Chiu TH, Hsieh TT. Risk factors for placental abruption in an Asian population. Reprod Sci 2007; 14:59-65.
39. Lamminpää R, Vehviläinen-Julkunen K, Gissler M, Selander T, Heinonen S. Pregnancy outcomes of overweight and obese women aged 35 years or older - a registry-based study in Finland. Obes Res Clin Pract 2016; 10: 133-42.

40. Lao TT, Sahota DS, Cheng YKY, Law LW, Leung TY. Advanced maternal age and postpartum hemorrhage-risk factor or red herring? J Matern Fetal Neonatal Med 2014; 27:243-6.

41. Carolan MC, Davey M-A, Biro M, Kealy M. Very advanced maternal age and morbidity in Victoria, Australia: a population based study. BMC Pregnancy Childbirth 2013; 13:80.

42. Chawanpaiboon S, Hengrasmee P. Adverse pregnancy outcomes in extremely maternal age. Open J Obstet Gynecol 2013; 3:427-34.

43. Räisänen S, Gissler M, Nielsen HS, Kramer MR, Williams MA, Heinonen S. Social disparity affects the incidence of placental abruption among multiparous but not nulliparous women: a register-based analysis of 1,162,126 singleton births. Eur J Obstet Gynecol Reprod Biol 2013; 171:246-51.

44. Traisrisilp K, Tongsong T. Pregnancy outcomes of mothers with very advanced maternal age (40 years or more). J Med Assoc Thai 2015; 98:117-22.

45. Ebrahim MA, Zaiton F, Elkamash TH. Clinical and ultrasound assessment in patients with placenta previa to predict the severity of intrapartum hemorrhage. Egyptian Journal of Radiology and Nuclear Medicine 2013; 44:657-63.

46. Ananth CV, Wilcox AJ, Savitz DA, Bowes WA, Luther ER. Effect of maternal age and parity on the risk of uteroplacental bleeding disorders in pregnancy. Obstet Gynecol 1996; 88:511-6.

47. Gilliam M, Rosenberg D, Davis F. The likelihood of placenta previa with greater number of cesarean deliveries and higher parity. Obstet Gynecol 2002; 99:976-80. 


\section{Resumo}

Este estudo teve como objetivo investigar a existência e magnitude da associação entre idade materna avançada (AMA) e ocorrência de placenta prévia $(P P)$ e descolamento placentário $(D P)$ entre mulheres nuliparas e multíparas, por meio de uma revisão sistemática e meta-análise. Nós pesquisamos artigos publicados entre 1o de janeiro de 2005 e 31 de dezembro de 2015, em qualquer idioma, nos seguintes bancos de dados: PubMed, Scopus, Web of Science e LILACS. As mulheres foram agrupadas em duas categorias de idade: até 34 anos e 35 anos ou mais. A Escala Newcastle-Ottawa foi utilizada para avaliar a qualidade metodológica dos estudos. Uma meta-análise foi realizada para os desfechos PP e DP, usando um modelo de meta-regressão para encontrar possíveis covariáveis associadas à heterogeneidade entre os estudos e o teste de Egger para avaliar o viés de publicação. O protocolo desta revisão sistemática foi registrado no sistema PROSPERO (CRD42016045594). Vinte e três estudos preencheram os critérios e foram incluídos na meta-análise. Para ambos os resultados, um idade mais avançada aumentou a magnitude da associação, e PP (OR = 3,16, IC95\%: 2,79-3,57) foi mais fortemente associado com AMA do que $D P(O R=1,44$, IC95\%: 1,35-1,54). Ao estratificar por paridade, não houve diferença entre nulíparas e multíparas de idade materna avançada para os desfechos de PP e DP. Nossa revisão forneceu evidências de baixa qualidade para ambos os resultados, uma vez que abrange estudos observacionais com alta heterogeneidade estatística, diversidade de populações, sem controle de fatores de confundimento em vários casos e viés de publicação. No entanto, os intervalos de confiança eram pequenos e há um gradiente dose-resposta, bem como uma grande amplitude de efeito para o PP.

Idade Materna; Placenta Prévia; Descolamento Prematuro da Placenta; Complicações na Gravidez

\section{Resumen}

Este estudio tuvo como objetivo investigar la existencia y la magnitud de la asociación entre la edad materna avanzada (AMA) y la aparición de placenta previa $(P P)$ y desprendimiento de la placenta $(D P)$ entre mujeres nuliparas y multíparas, mediante una revisión sistemática y un metanálisis. Se realizaron búsquedas en los artículos publicados entre el 1o de enero de 2005 y el 31 de diciembre de 2015, en cualquier idioma, en las siguientes bases de datos: PubMed, Scopus, Web of Science y LILACS. Las mujeres se agruparon en dos categorías de edad: hasta 34 años y 35 años o más. La Escala Newcastle-Ottawa se utilizó para evaluar la calidad metodológica de los estudios. Se realizó un metanálisis para los resultados de PP y DP, utilizando un modelo de metarregresión para encontrar posibles covariables asociadas con la heterogeneidad entre los estudios y la prueba de Egger para evaluar el sesgo de publicación. El protocolo de esta revisión sistemática se registró en el Sistema PROSPERO (CRD42016045594). Veintitrés estudios cumplieron los criterios y se incluyeron en el metanálisis. Para ambos resultados, una edad más avanzada aumentó la magnitud de la fuerza de asociación, y $P P(O R=3,16$, IC95\%: 2,79-3,57) se asoció más fuertemente con AMA que DP $(O R=1,44$, IC95\%: 1,35-1,54). Cuando se estratificó por paridad, no hubo diferencia entre las mujeres nulíparas y las multíparas consideradas mayores para los resultados de PP y DP. Nuestra revisión proporcionó pruebas de muy baja calidad para ambos resultados, ya que abarca estudios observacionales con alta heterogeneidad estadistica, diversidad de poblaciones, ausencia de control de los factores de confusión en varios casos y sesgo de publicación. Sin embargo, los intervalos de confianza fueron pequeños y existe un gradiente de dosis-respuesta, así como una gran magnitud de efecto para PP.

Edad Materna; Placenta Previa; Desprendimiento Prematuro de la Placenta; Complicaciones del Embarazo
Submitted on 06/Dec/2016

Final version resubmitted on 04/Oct/2017

Approved on 09/Oct/2017 